\title{
Efektifitas Digital Marketing Terhadap Kualitas Layanan pada Usaha di Masa Pandemi Covid 19 (Studi Kasus di Aceh)
}

\author{
Muhammad IQBAL * \\ Fakultas Ekonomi, STIES Aceh Jaya, \\ Kabupaten Aceh Jaya, Provinsi Aceh, Indonesia \\ ibal.surat@gmail.com
}

\section{Article's history:}

Received 19 August 2021; Received in revised form 13 December 2021; Accepted 15 December, 2021; Published 30 December 2021. All rights reserved to the Lembaga Otonom Lembaga Informasi dan Riset Indonesia (KITA INFO dan RISET).

Suggested citation:

Iqbal, M., 2021. Efektifitas Digital Marketing terhadap Kualitas Layanan pada Usaha di Masa Pademi Covid 19 (Studi Kasus di Aceh). JEMSI (Jurnal Ekonomi, Manajemen, dan Akuntansi), Volume 7 (2): 83-93. DOI: https://doi.org/10.35870/jemsi.v7i2.609.

\section{ABSTRAK:}

Penelitian ini bertujuan untuk menguji pengaruh Digital Marketing terhadap Kualitas Layanan melalui Media Iklan Digital. Digital Marketing dengan indicator Accessibility, Interactivity, Entertainment, Credibility, Irritation dan Informativeness. Kualitas Layanan dengan Indikator Tangibles, Reliability, Responsiveness, Assurance, Empathy. Populasi dalam penelitian ini adalah para pengusaha yang berjualan melalui Media Iklan Digital yang berada di wilayah Aceh. Teknik pengambilan sampel menggunakan teknik porposive sampling dengan metode sampling jenuh dengan 150 responden. Metode analisis data yang digunakan adalah regresi linear sederhana. Hasil pengujian menunjukkan variable Digital Marketing secara persial berpengaruh signifikan terhadap kualitas layanan melalui Media Iklan Digital.

Kata Kunci: Digital Marketing; Kualitas Layanan.

JEL Classification: M31; Z3 ; L15.

\section{PENDAHULUAN}

Perkembangan dunia digital saat ini sangat berkembang pesat dan memberi dampak perubahan yang besar pada gaya hidup masyarakat terutama di Indonesia. Di Era revolusi Indrutri 4.0 merupakan revolusi yang menitikberatkan pada otomatisasi serta kolaborasi antara teknologi saber (Andrew:2021). Dimana akses informasi dan beberapa aktifitas yang sulit di jangkau saat ini dengan mudah dapat dilakukan. Perkembangan diantaranya: Internet of Think (loT), Big Data, Augmented Reality, Cyber Security, Artificial Intelligence (Al), Additive Manufacturing, Simulation, System Integration, Cloud computing. Perkembangan tersebut telah memberikan dampak besar bagi dunia usaha saat ini, diantaranya banyak bermunculan perusahaan rintisan (Unicorn) baru dengan nilai kapitalisasi lebih dari \$1 miliar. (Aileen Lee:2013) sehingga mampu memberikan sentiment positif pada investor asing terharap pertumbuhan ekonomi Indonesia saat ini. Oleh karena itu, penting bagi entrepreneurship muda dalam dalam memahami peran digital marketing sehingga mampu memberikan peningkatan terhadap nilai usaha yang sedang atau telah dirintis.

Saat ini Indonesia dalam masa pademi, sehingga menjadi tantangan bagi usahawan dalam melakukan aktivitas usaha. Menurut survei Asian Development Bank terdapat 2.509 UMKM secara nasional menunjukkan bahwa pelaku UMKM yang harus tutup sementara. Usaha Mikro, Kecil, dan Menengah (UMKM) memiliki peran penting bagi perekonomian nasional. Sebab UMKM berkontribusi terhadap Produk Domestik Bruto (PDB) sebesar 61,07 persen atau senilai Rp 8.573 triliun. (Elsa:2021) Sehingga pemerintah terus mestimulus pertumbuhan usahawan agar mampu bangkit. Pemerintah mendorong pelaku Usaha untuk ikut berjualan di platform digital (go digital), data saat ini menunjukkan terdapat 11,7 juta Usaha bergabung dengan platform digital. 
Di provinsi Aceh sendiri, terdapat sejumlah koperasi \& umkm yang tersebar di beberapa kabupaten dan kota, menurut data Umkm (acehprov:2021) total umkm: 74.810 total koperasi: 5.978. Sedangkan data statistik koperasi aktif $\&$ tidak aktif di kabupaten kota aceh total jumlah aktif $=2713$, total jumlah tidak aktif $=3265$. Adapun informasi selengkapnya terdapat pada table berikut:

Tabel 1. Data Jumlah UMKM Binaan Dinas Koperasi dan UMKM Aceh di 20 Kabupaten/ Kota.

\begin{tabular}{|c|c|c|c|}
\hline No & Kota & Koperasi & UMKM \\
\hline 1. & Banda Aceh & 43 & 9591 \\
\hline 2. & Aceh Besar & 600 & 4455 \\
\hline 3. & Sigli & 33 & 1545 \\
\hline 4. & Biruen & 308 & 6997 \\
\hline 5. & Lhokseumawe & 256 & 2353 \\
\hline 6. & Aceh Utara & 484 & 3660 \\
\hline 7. & Aceh Timur & 410 & 5891 \\
\hline 8. & Aceh Tamiang & 263 & 2948 \\
\hline 9. & Bener Meriah & 270 & 1010 \\
\hline 10. & Aceh Tengah & 431 & 2719 \\
\hline 11. & Gayo Lues & 141 & 996 \\
\hline 12. & Aceh Tenggara & 501 & 1245 \\
\hline 13. & Aceh Jaya & 135 & 1212 \\
\hline 14. & Aceh Barat & 328 & 2010 \\
\hline 15. & Simuelue & 108 & 2087 \\
\hline 16. & Aceh Barat Daya & 189 & 2262 \\
\hline 17. & Singkil & 127 & 1473 \\
\hline 18. & Aceh Selatan & 406 & 3251 \\
\hline 19. & Nagan Raya & 199 & 6451 \\
\hline \multirow[t]{2}{*}{20.} & Langsa & 338 & 3579 \\
\hline & & 5.570 & 65.735 \\
\hline
\end{tabular}

Sumber: Provinsi Aceh (2021)

Dari keterangan tersebut memperlihatkan bahwa besarnya potensi umkm di aceh menjadi salah satu alasan pengembangan digital marketing sebagai media pengembangan dan promosi usaha sehingga mampu memberikan dampak positif pada usaha melalui media internet. Dengan menggunakan digital marketing, pelaku usaha dapat menekan biaya promosi tanpa harus turun ke lapangan. Penggunaan internet saat ini sudah menjadi kebutuhan bagi masyarakat. Hasil survei Asosiasi Penyelenggara Jasa Internet Indonesia (APJII) periode 2019kuartal II/2020 mencatat, jumlah pengguna internet di Indonesia mencapai 196,7 juta jiwa. Sedangkan total penduduk Indonesia secara keseluruhan sebesar 269,6 juta jiwa (Databox:2020) Di Aceh sendiri terdapat 3.7 Juta pengguna aktif internet, dimana jumlah penduduk 5.3 Juta jiwa. (BPS:2021) Peningkatan jumlah pengguna internet ini disebabkan oleh berkembangnya infrastruktur dan kemudahan masyarakat untuk mendapatkan gadget.Artinya $80 \%$ lebih market bisa di jangkau melalui internet.

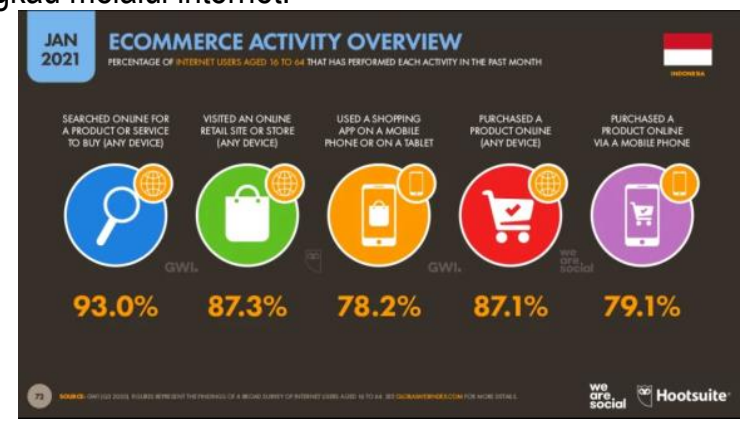

Gambar 1. Aktivitas Belanja Online di Indonesia

Gambar satu di atas memperlihatkan bahwa sebanyak 93.0\% pengguna internet di Indonesia melakukan pencarian barang atau jasa melalui online, $87.3 \%$ pengguna mengunjungi toko online, $78.2 \%$ pengguna melakukan 
transaksi online via handphone atau laptop, $87.1 \%$ pengguna lainnya melakukan transaksi online melalui internet. Dan $79.1 \%$ pengguna menggunakan smartphone untuk membayar produk yang mereka beli melalui aplikasi ePayment atau Mobile Banking. Hal ini memperlihatkan bahwa potensi belanja online dan penggunaan internet sebagai media untuk mempromosikan usaha cukup berkembang di Indonesia

Media periklanan digital saat ini telah berkembang dengan sangat baik, penyajian informasi yang ringkas dengan analisis pasar yang dikembangkan menggunakan teknologi internet memungkinkan iklan dapat masuk sesuai dengan kebutuhan usaha dan tingkat usia yang dibutuhkan dalam sebuah produk. Sehingga dampak yang diberikan dari iklan digital juga lebih tepat sasaran. Adapun beberapa perikalanan digital yang dikembangkan oleh perusahaan media social saat ini seperti Google Ads, Facebook Ads, Youtube Ads, Tiktok Ads dan masih banyak lagi media platform Media Sosial lainnya yang turut berkecimpung dalam pengembangan Adsens (Periklanan Digital) saat ini. Disamping itu, terdapat pula platform digital yang turut memberikan kontribusi dalam meningkatkan daya beli masyarakat terhadap produk umkm di Indonesia diantaranya Tokopedia, Shopee, Bukalapak, Olx,Blibli, Lazada, Gofood, Maxim, Grab dan masih banyak lagi lainnya yang telah dijadikan sebagai marketplace untuk meningkatkan daya beli produk usaha. Menurut data dari We are Social, yang merupakan sebuah agensi digital marketing di Amerika, menyatakan bahwa platform media sosial yang sering digunakan di Indonesia per-jan 2021 total Periklanan Digital di Indonesia pada tahun 2020 telah mengakumulasi nilai sebesar 1.45 Milyar USD, 515.8 Juta USD dihasilkan dari Pencarian Digital, 439.2 Juta USD dihasilkan dari Sosial Media, 268.6 Juta USD dihasilkan dari Banner Ads, 183.2 Juta USD dihasilkan dari Video Iklan dan 43.43 Juta USD dihasilkan dari Periklanan lainnya.

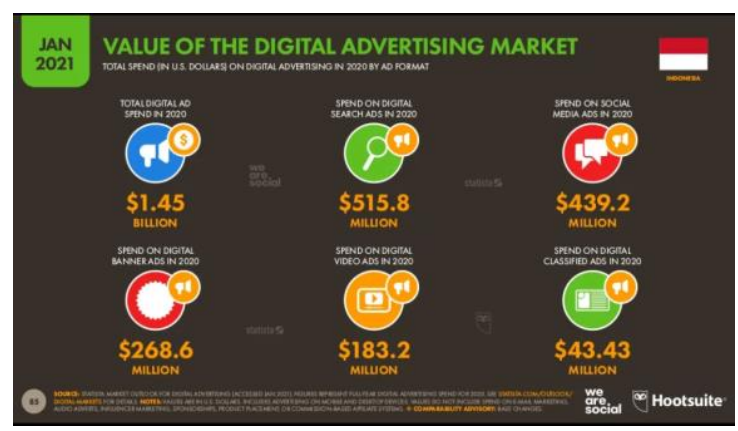

Gambar 2. Akumulasi Laba dari Digital Marketing

Teknologi saat ini terus berkembang dan manfaat penggunaan internet terasa bagi para pemakainya. Beberapa orang merasa ketergantungan dengan adanya internet, termasuk aktivitas Usaha Mikro Kecil dan Menengah (UKM) dalam memanfaatkan teknologi informasi untuk menjalankan usahanya khususnya pada era Masyarakat Ekonomi ASEAN (MEA). (Febriyantoro:2018). Pengusaha di Indonesia harus mampu meningkatkan nilai usaha yang kompetitif sehingga punya daya saing sehingga mampu bertahan pada masa pademi serta memiliki kaulitas ekspor agar dapat bertahan pada kancah ekonomi global seperti saat ini. Teknologi tentu akan sangat memberi andil dalam peningkatan nilai usaha tersebut, seandainya dalam dunia bisnis peranan Teknologi Informasi dimanfaatkan dengan maksimal maka perdagangan secara elektronik (E-Commerce). E-commerce merupakan bagian dari e-business, di mana cakupan e-business lebih luas, tidak hanya sekedar perniagaan tetapi mencakup juga pengkolaborasian mitra bisnis, pelayanan nasabah, lowongan pekerjaan dan lain-lain. Manfaat yang bisa didapat dari pemanfaatan teknologi oleh pengusaha tentusaja Mempermudah Cara Komunikasi, Memberikan Pengetahuan dan Sumber Informasi, Manajemen Data, Sistem Informasi Manajemen, Customer Relationship Management, Aktivitas Bisnis Selama 24 Jam. (Arfifin:2021) Sehingga urgensi bagi Pengusaha dalam memahami teknologi menjadi sangat penting, sehingga pengusaha perlu mempelajari teknologi informasi dengan baik dan tepatguna agar dapat memaksimalkan hasil.

Digital marketing menjadi salah satu media yang sering digunakan oleh pelaku usaha karena kemampuan baru konsumen dalam mengikuti arus digitalisasi, beberapa perusahaan sedikit demi sedikit mulai meninggalkan model pemasaran konvesional/dan beralih ke pemasaran moderen. Dengan digital marketing komunikasi dan transaksi dapat dilakukan setiap waktu/real time dan bisa di akses ke seluruh dunia, seseorang juga dapat melihat berbagai barang melalui internet, sebagian besar informasi mengenai berbagai produk sudah tersedia di internet, kemudahan dalam pemesanan dan kemampuan konsumen dalam membandingkan satu produk dengan produk lainnya (Kotler \& Keller, 2008). 


\section{TINJAUAN KEPUSTAKAAN}

\section{Pengertian Digital marketing}

Digital marketing adalah kegiatan pemasaran termasuk branding yang menggunakan berbagai media. Sebagai contoh yaitu blog, website, e-mail, adwords, dan berbagai macam jaringan media sosial. Ridwan Sanjaya \& Josua Tarigan (2009) P E-Marketing atau digital marketing diartikan sebagai penggunaan teknologi digital untuk mencapai tujuan pemasaran serta upaya pengembangan atau penyesuaian konsep pemasaran itu sendiri, dapat berkomunikasi dalam cakupan global, dan mengubah cara perusahaan melakukan bisnis dengan pelanggan (Ali, 2013). Digital marketing merupakan pemasaran dengan menggunakan penerapan teknologi secara digital. Salah satu bentuk marketing digital dengan menggunakan media elektronik atau internet adalah internet marketing (emarketing). E-Marketing merupakan suatu proses pemasaran yang menggunakan teknologi komunikasi elektronik, khususnya internet. Peran strategi digital marketing dapat menjadi hal yang penting dalam mengikuti perkembangan teknologi digital dan mengembangkan rencana untuk menarik konsumen dan mengarahkannya pada perpaduan antara komunikasi elektornik dan komunikasi tradisional (Chaffey, Chadwick, Mayer, \& Johnston, 2009).

Hadirnya digital marketing disebabkan oleh majunya perkembangan teknologi dengan Web 2.0 yang dibarengi dengan mobile technology, dikutip dari buku Cracking one karya Rhenald Kasali (2011) di mana dengan mobile technologi, setiap orang yang memiliki jaringan internet, dapat mendapatkan informasi akurat hanya dalam genggaman. Digital marketing juga diartikan sebagai kegiatan pemasaran yang menggunakan media berbasis internet (Wardhana, 2015). Konsep pemasaran digital berasal dari mesin pencari internet dan situs web. Ketika penggunaan internet meledak pada tahun 2001, pasar didominasi oleh Google dan Yahoo sebagai mesin pencari optimasi (SEO). Definisi Pemasaran digital menurut American Marketing Association (AMA) adalah aktivitas, institusi, dan proses yang difasilitasi oleh teknologi digital dalam menciptakan, mengomunikasikan, dan memberikan nilai kepada konsumen dan pemangku kepentingan lainnya (Kannan \& Hongshuang, 2016). Ali Hasan (2013) mendeskripsikan bahwa pemasaran digital mempunyai sejumlah karakteristik sebagai berikut:

1) Upaya meningkatkan interaktivitas bisnis dengan pelanggan yang bergantung pada teknologi.

2) Sebuah dialog elektronik (teknologi interaktif) untuk memberikan akses informasi kepada pelanggan (komunitas, individu), dan sebaliknya.

3) Upaya melakukan semua kegiatan bisnis melalui internet untuk tujuan penelitian, analisis dan perencanaan untuk menemukan, menarik, dan mempertahankan pelanggan.

4) Upaya meningkatkan akselarasi jual beli barang dan jasa (tertentu), informasi dan ide melalui internet.

5) Konsumen saat ini memperhatikan konten yang.dipaparkan oleh pemasar sehingga membebtuk pemikiran irasional yang bertujuan untuk mempengaruhi keputusan pembelian para konsumen (Febriyantoro, M.T, 2016)

\section{Media Digital Marketing}

Media sosial didefinisikan sebagai sekelompok aplikasi berbasis internet yang menciptakan fondasi ideologi dan teknologi dari Web 2.0 yang memungkinkan penciptaan dan pertukaran user generated content (Stockdale, Ahmed, \& Scheepers, 2012). Aplikasi media social tersedia mulai dari pesan instan hingga situs jejaring sosial yang menawarkan pengguna untuk berinteraksi, berhubungan, dan berkomunikasi satu sama lain. Aplikasiaplikasi ini bermaksud dengan tujuan utama meraih (engage) masyarakat. Dalam konteks bisnis, people engagement dapat mengarah kepada penciptaan profit. Adapun Jenis Media Digital Marketing dijelaskan pada Jurnal Enterpreneur meliputi Website, Search Engine Marketing (SEO), Social Media Marketing, Online Advertising, Email Marketing, Video Marketing. (Yuliastini: 2022)

Menurut Yazer Nasdini (2012:32) indikator Digital Marketing yaitu :

1) Accessibility (aksessibilitas). adalah kemampuan pengguna untuk mengakses informasi dan layanan yang disediakan secara online periklanan. istilah Accessibility umumnya terkait dengan cara pengguna dapat mengakses situs Sosial media.

2) Interactivity (interaktivitas). adalah Tingkat komunikasi dua arah yang mengacu pada kemampuan timbal balik komunikasi antara pengiklan dan konsumen, dan menanggapi input yang mereka terima.

3) Entertainment (hiburan). adalah kemampuan beriklan untuk memberi kesenangan atau hiburan kepada konsumen. Secara umum memang banyak iklan yang memberikan hiburan sambil menyisipkan informasiinformasi. 
4) Credibility (kepercayaan). adalah bagaimana tingkat kepercayaan konsumen online iklan yang muncul, atau sejauh mana iklan memberikan informasi tentang mereka dapat dipercaya, tidak memihak, kompeten, kredibel dan spesifik.

5) Irritation (Gangguan). adalah gangguan yang terjadi dalam iklan online, seperti manipulasi iklan sehingga mengarah pada penipuan atau pengalaman buruk konsumen tentang periklanan online.

6) Informativeness (informative). Kemampuan iklan untuk menyuplai informasi kepada konsumen adalah hakekat dari sebuah iklan. Iklan juga harus memberikan gambaran yang sebenarnya mengenai sebuah produk sehingga bisa memberikan keuntungan ekonomis bagi konsumen.

Strategi Digital Marketing dalam mencapai target pengguna untuk menjangkau pasar yakni menggunakan: Search Engine Optimization (SEO), Content Marketing, Otomatisasi Pemasaran, Pay-Per-Klik (PPC), Native Advertising, Affiliate Marketing, Sosial Media Marketing. (Yuliastini: 2022). Wardhana (2015) menemukan bahwa strategi digital marketing berpengaruh hingga 78\% terhadap keunggulan bersaing UMK dalam memasarkan produknya. Pemanfaatan digital marketing memiliki beberapa keunggulan, antara lain:

1) Target bisa diatur sesuai demografi, domisili, gaya hidup, dan bahkan kebiasaan;

2) Hasil cepat terlihat sehingga pemasar dapat melakukan tindakan koreksi atau perubahan apabila dirasa ada yang tidak sesuai;

3) Biaya jauh lebih murah daripada pemasaran konvensional;

4) Jangkauan lebih luas karena tidak terbatas geografis;

5) Dapat diakses kapanpun tidak terbatas waktu;

6) Hasil dapat diukur, misalnya jumlah pengunjung situs, jumlah konsumen yang melakukanpembelian online;

7) Kampanya bisa dipersonalisasi;

8) Bisa melakukan engagement atau meraih konsumen karena komunikasi terjadi secara langsung dan dua arah sehingga pelaku usaha membina relasi dan menumbuhkan kepercayaan konsumen.

\section{Kualitas Layanan}

Kualitas Layanan Menurut Tjiptono (2021) Kualitas jasa merupakan sesuatu yang dipersepsikan oleh pelanggan.Pelanggan akan menilai kualitas sebuah jasa yang dirasakan berdasarkan apa yangmereka deskripsikan dalam benak mereka. Pelanggan akan beralih ke penyediajasa lain yang lebih mampu memahami kebutuhan spesifik pelanggan danmemberikan layanan yang lebih baik. Ada 5 dimensi kualitas jasa menurut Parasuraman, Zeithaml, dan Berry (2009:111) diantaranya adalah: Bukti Fisik (Tangibles) yaitu Berfokus pada elemen-elemen yang merepresentasikan pelayanan secara fisik yang meliputi fasilitas fisik, lokasi, perlengkapan dan peralatan yang dipergunakan (teknologi), serta penampilan pegawainya.Keandalan (Reliability) yaitu kemampuan untuk memberikan pelayanan sesuai dengan yang telah dijanjikan dengan tepat yang meliputi kesesuaian kinerja dengan harapan pelanggan yang berarti ketepatan waktu, pelayanan yang sama untuk semua pelanggan, sikap simpatik dan akurasi yang tinggi. Ketanggapan (Responsiveness) yaitu kemauan untuk membantu dan memberikan pelayananan yang cepat (responsif) dan tepat kepada pelanggan dengan informasi yang jelas. Dimensi ini menekankan padaperilaku personel yang memberi pelayanan untuk memperhatikan permintaan, pertanyaan, dan keeratan dari para pelanggan.Jaminan (Assurance) yaitu kemampuan untuk melahirkan kepercayaan dan keyakinan pada diri pelanggan yang meliputi pengetahuan, kesopansantunan dan kemampuan para pegawai perusahaan untuk menumbuhkan rasa percaya para pelanggan kepada perusahaan.Empati (Empathy) yaitu menekankan pada perlakuan konsumen sebagai individu yang meliputi syarat untuk peduli, memiliki pengertian dan pengetahuan tentang pelanggan, memahami kebutuhan pelanggan secara spesifik, serta memiliki waktu pengoperasian yang nyaman bagi pelanggan.

\section{METODE PENELITIAN}

Penelitian ini menggunakan metode kuantitatif, dengan menggunakan model observasi dan sampel berupa data kuesioner terhadap pelaku usaha. Menurut Sugiyono $(2018 ; 13)$ data kuantitatif merupakan metode penelitian yang berlandaskan positivistic (data konkrit), data penelitian berupa angka-angka yang akan diukur menggunakan statistik sebagai alat uji penghitungan, berkaitan dengan masalah yang diteliti untuk menghasilkan suatu 
kesimpulan. penelitian kuantitatif bertujuan untuk menjelaskan hubungan antarvariabel, menguji teori, dan melakukan generalisasi atas objek penelitian.

\section{Kerangka Penelitian}

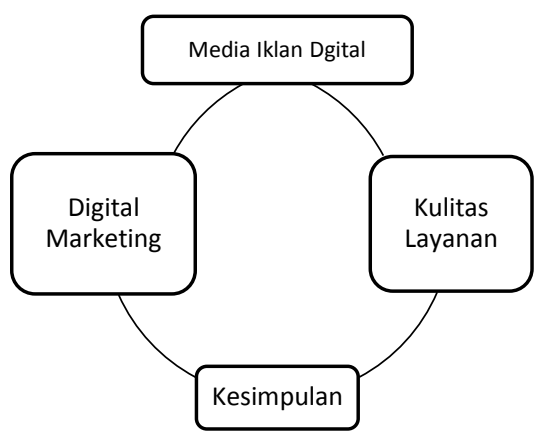

Gambar 3. Bagan Kerangka Penelitian

Penelitian ini menguji 2 variable yakni hubungan digital marketing dengan kualitas layanan pada media iklan digital di Aceh, kemudian ditarik kesimpulan yang akan menjadi hasil penelitian ini. Besaran sample penelitian ini berjumlah 150 orang. Hal ini disebabkan karena penggunaan sampel yang besar dalam penelitian kuantitatif dianggap akan menghasilkan perhitungan statistik yang lebih akurat daripada sampel dalam jumlah kecil (Kumar, 1999). Kerlinger dan Lee (2000) menyarankan sebanyak 30 sampel sebagai jumlah minimal sampel dalam penelitian kuantitatif. Teknik sampling yang digunakan oleh peneliti adalah purposive sample. Purposive sample adalah teknik penentuan sampel dengan pertimbangan tertentu (Sugiyono, 2009:85). Kemudian menurut Arikunto (2010) dalam pemilihan sampel secara purposive pada sebuah penelitian akan berpedoman pada syarat-syarat yang harus dipenuhi sebagai berikut:

1) Pengambilan sampel harus didasarkan atas ciri-ciri, sifat-sifat atau karakteristik tertentu, yang merupakan ciri-ciri pokok populasi.

2) Subjek yang akan diambil sebagai sampel harus benar-benar merupakan subjek yang paling banyak mengandung ciri-ciri yang terdapat pada populasi (key subjectis).

3) Penentuan karakteristik populasi dilakukan dengan cermat di dalam studi pendahuluan.

Teknik pengolahan data kuantitatif merupakan metode yang digunakan ketika penelitian menggunakan data bertipe numerik atau angka seperti data statistik, data total penjualan, dan lain sebagainya. (DQLab:2021). Pada penelitian ini, data diolah menggunakan SPSS dan Microsoft Excel dengan menggunakan model Analisis Regresi linier Sederhana. Analisis regresi linear sederhana adalah salah satu metode statistika yang digunakan untuk mengetahui hubungan fungsional sebuah variabel tidak bebas (dependent variable) dengan dua atau lebih variabel bebas (independent variable) (Neter, 1997). Pada penelitian dengan menggunakan metode regresi linier sederhana ini data yang digunakan adalah data interval atau rasio.

\section{Uji t dan Uji Determinasi $\left(R^{2}\right)$}

Uji $t$ digunakan untuk mengetahui pengaruh masing- masing variabel independen terhadap variabel dependen (Widjarjono, 2010). Menurut Kuncoro (2009), uji F digunakan untuk menguji signifikan tidaknya pengaruh variabel bebas secara simultan terhadap variabel terikat.

\section{ANALISA DAN PEMBAHASAN}

\section{Penelitian Terdahulu}

Febriyantoro, M.T. (2018), Pemanfaatan Digital Marketing Bagi Usaha Mikro, Kecil Dan Menengah Pada Era Masyarakat Ekonomi Asean. Dari hasil penelitian diketahui bahwa digital marketing memudahkan pelaku UMKM untuk memberikan informasi dan berinteraksi secara langsung dengan konsumen, memperluas pangsa pasar, meningkatkan awareness dan meningkatkan penjualan bagi pelaku UKM. Silviana, Ms (2020) Pengaruh 
Digital Marketing Terhadap Tingkat Penjualan Melalui Sosial Media (Studi Kasus Di Kecamatan Bone-Bone). Skripsi thesis, Universitas Muhammadiyah Palopo. Hasil pengujian menunjukkan bahwa variabel Digital Marketing secara parsial berpengaruh signifikan terhadap tingkat penjualan melalui media sosial.

\section{Pengujian Hasil Analisis}

Aceh dengan luas wilayah $58.377 \mathrm{~km}^{2}$ dan 5,372 juta (2019) terdapat 65.735 UMKM dan 5.570 Koperasi yang tersebar di seluruh wilayah. Adapun hasil dari penelitian ini menunjukkan bahwa untuk karakteristik Jenis Kelamin:

Table 2. Jenis Kelamin

\begin{tabular}{lcc}
\multicolumn{1}{c}{ Jenis Kelamin } & Frekuensi & Persentase \\
\hline Laki-Laki & 110 & 73.3 \\
Perempuan & 40 & 26.7 \\
Total & 150 & 100 \\
\hline
\end{tabular}

Berdasarkan tabel 2 terdapat $73.3 \%$ sampel dari pihak laki-laki dan $26.7 \%$ dari perempuan.

Table 3. Tingkatan Umur

\begin{tabular}{|c|c|c|}
\hline Umur & Frekuensi & Persentase \\
\hline$<20-30$ & 48 & 32.0 \\
\hline $31-40$ & 26 & 17.3 \\
\hline $41-50$ & 40 & 26.7 \\
\hline $51->60$ & 36 & 24.0 \\
\hline Total & 150 & 100 \\
\hline
\end{tabular}

Bedasarkan dari tabel 3 kombinasi umur paling tinggi pada umur 20-30 tahun dengan 32\% dan 41-50 tahun sebanyak $26.7 \%$

Table 4. Periode Usaha

\begin{tabular}{|c|c|c|}
\hline Tahun & Frekuensi & Persentase \\
\hline$<2-3$ & 32 & 21.3 \\
\hline $4-5$ & 29 & 19.3 \\
\hline $6-7$ & 45 & 30.0 \\
\hline $8->9$ & 44 & 29.3 \\
\hline Total & 150 & 100 \\
\hline
\end{tabular}

Periode usaha pada tabel 4 menunjukkan $30 \%$ usaha sudah berjalan selama $6-7$ tahun dan $29 \%$ sudah berjalan 8-9 tahun.

Table 5. Statistik Descriptiv

\begin{tabular}{lrrrrrr}
\hline & Mean & Min & Max & Std. Dev. & N \\
\hline Kepuasan Layanan & 16.19 & 5 & 25 & 5.373 & 150 \\
Digital Marketing & 18.41 & 6 & 30 & 4.735 & 150 \\
\hline
\end{tabular}

Dari tabel 5 menunjukkan 150 data sampel pada Digital Marketing $(X)$, nilai Mean sebesar 18,41, nilai standart deviasi sebesar 4,735. Dan pada Kepuasan Layanan dengan Mean 16,19 dan nilai Standar deviasi 5.373 Ini menunjukkan bahwa nilai rata-rata Digital Marketing $(X)$ dan Kepuasan Layanan $(Y)$ lebih besar dari pada nilai standart deviasi sehingga penyimpangan data yang terjadi rendah maka penyebaran nilainya merata. Untuk tingkat validitas, dilakukan uji signifikansi dengan membandingkan $r_{\text {hitung }}$ dengan $r_{\text {tabel. }}$. Apabila $r_{\text {hitung }}$ lebih besar dari $r_{\text {abel }}($ $\left.r_{\text {hitung }}>r_{\text {tabel }}\right)$ dan nilai $r$ positif maka butir pertanyaan tersebut dapat dikatan valid, dan sebaliknya jika $r_{\text {hitung }}$ lebih kecil dari $\mathrm{r}_{\text {tabel }}\left(\mathrm{r}_{\text {hitung }}<\mathrm{r}_{\text {tabel }}\right)$ maka butir pertanyaan tersebut tidak valid. 
Table 6. Tabel Uji Validasi

\begin{tabular}{lllll}
\hline \multicolumn{1}{c}{ Variable } & & \multicolumn{1}{c}{ rhitung } & r $_{\text {tabel }}$ & Ket \\
\hline Digital & Aksesibilitas & 0,70 & 0.159 & Valid \\
Marketing & Interaktivitas & 0,71 & 0.159 & Valid \\
& Hiburan & 0,73 & 0.159 & Valid \\
& Kredibilitas & 0,70 & 0.159 & Valid \\
& Gangguan & 0,56 & 0.159 & Valid \\
& Informatif & 0,28 & 0.159 & Valid \\
Kualitas & Berwujud & 0,79 & 0.159 & Valid \\
Layanan & Keandalan & 0,84 & 0.159 & Valid \\
& Daya tanggap & 0,76 & 0.159 & Valid \\
& Jaminan & 0,82 & 0.159 & Valid \\
& Empati & 0,76 & 0.159 & Valid \\
\hline
\end{tabular}

Sumber Data Diolah Tahun 2021

Dari tabel 6 hasil uji validitas di atas terlihat bahwa nilai $r_{\text {hitung }}$ lebih besar dibandingkan dengan $r_{\text {tabel }}$ dengan alpha 0,05 atau 5\%, maka dapat disimpulkan bahwa semua indikator dari kedua variabel $X$ dan $Y$ adalah valid. Untuk mengukur reliabilitas dengan menggunakan uji statistik adalah cronbach alpha (a).

Table 7. Hasil Uji Reabilitas

\begin{tabular}{ccccc} 
Variabel & \multicolumn{1}{c}{$\begin{array}{c}\text { Reliabilitas } \\
\text { Coefisien }\end{array}$} & Alpha & Batas Reliabilitas & Ket \\
Digital Marketing & 6 Item & 1,20 & 0.60 & Reliabel \\
Kualitas Layanan & 5 Item & 1,25 & 0.60 & Reliabel \\
\hline
\end{tabular}

Dari tabel 7 hasil uji reliabilitas di atas dapat diketahui bahwa masing-masing variabel memiliki nilai cronbach alpha (a) lebih dari 0,60 (>0,60). Sebingga dapat disimpulkan bahwa semua variabel $\mathrm{X}$ dan $\mathrm{Y}$ adalah reliabel dan data dapat digunakan sebagai alat ukur instrument dalam penelitian ini.

\section{Analisis Penelitian}

Pada penelitian ini, regresi linear sederhana digunakan untuk menjawab hipotesa apakah Digital Marketing berpengaruh secara positif terhadap Kepuasan Layanan di Aceh

Table 8. Hasil Persamaan Regresi Linear Sederhana

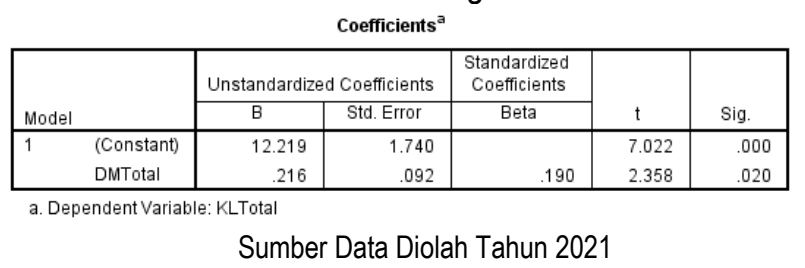

Pada Tabel 8 Hasil persamaan regresi linear sederhana di atas dikemukakan baha nilai koefisien dari persamaan regresi. Dalam penelitian regresi sederhana yang digunakan adalah sebagai berukut:

Dimana :

$$
Y=a+b X
$$

$Y=$ Kepuasan Layanan

$X=$ Digital Marketing

Dari output di atas menghasilkan model persamaan regresi :

$$
Y=12,219+0,216 X
$$


Nilai konstanta yaitu 12,219 atau sebesar $122,19 \%$ dan koefisien regresi $X$ yaitu 0,216 atau sebesar $21,6 \%$., sehingga setiap tambahan $1 \%$ pada variabel $X$ maka terjadi kenaikan sebesar 0,216 atau sebesar $21,6 \%$ pada variabel $\mathrm{Y}$, sehingga dapat dikatakan bahwa variabel $\mathrm{X}$ berpengaruh positif terhadap variabel $\mathrm{Y}$. Uji t pada dasarnya bertujuan untuk menguji pengaruh variabel bebas atau variabel independent (Digital Marketing) terhadap variabel terikat atau variabel dependent (Kualitas Pelayanan) secara terpisah atau parsial. Hasil Analisis koefisien uji t di atas menunjukkan bahwa, thitung pada Digital Marketing sebesar 2,358. Dalam pengujian hipotesis untuk model regresi, derajat bebas ditentukan dengan rumus $n-k$. Dimana $n=$ banyak observasi/sampel sedangkan $k=$ banyaknya variabel (bebas dan terikat). Pada penelitian ini, nilai derajat bebas $(\mathrm{df})=150-2=148$, maka ditemukan $t_{\text {tabel }}$ sebesar 1,655. Maka kesimpulanya bahwa thitung $>t_{\text {tabel }}(2,358>1,655)$, dan nilai probabilitas signifikansi sebesar 0,032 ini berarti nilai ini berada dibawah taraf signifikansi $0,05(0,020<0,05)$. Dari analisis di atas dapat ditarik kesimpulan bahwa variabel Digital Marketing berpengaruh signifikan terhadap Kepuasan Layanan.

Table 1. Hasil Analisis Uji Koefisien Determinasi $\left(\mathrm{R}^{2}\right)$

\begin{tabular}{|l|l|r|r|r|}
\hline Model & $\mathrm{R}$ & $\mathrm{R}$ Square & $\begin{array}{c}\text { Adjusted } \mathrm{R} \\
\text { Square }\end{array}$ & $\begin{array}{c}\text { Std. Error of } \\
\text { the Estimate }\end{array}$ \\
\hline 1 & $.190^{\mathrm{a}}$ & .036 & .030 & 5.293 \\
\hline
\end{tabular}

a. Predictors: (Constant), DMTotal

Sumber Data Diolah Tahun 2021

Berdasarkan tabel di atas menunjukkan bahwa nilai koefisien determinasi $\left(R^{2}\right)$ sebesar 0,036 hal ini dapat disimpulkan bahwa variabel bebas (Digital Marketing) berkontribusi atau berpengaruh terhadap variabel terikat (Kepuasan Layana) sebesar 3,6\% sedangkan sisanya 96,4\% dipengaruhi oleh variabel-variabel diluar dari penelitian ini. Kemudian nilai adjusted $R$ square $\left(R^{2}\right)$ sebesar 0,190 atau sebesar $19 \%$ hal ini berarti hubungan antar kedua variabel dikategorikan cukup kuat. Selanjutnya nilai Adjusted $R$ Square diperoleh nilai 0,030 hal ini berarti bahwa model regresi pada penelitian ini sudah baik karena tidak bernilai negative. Sedangkan nilai Std. Error of the Estimate diperoleh nilai kesalahan standar etimasinya sebesar 5,293 hal ini berarti kesalahan model regresi dalam memprediksi variabel Kepuasan Layanan sebesar 5,293.

\section{Pembahasan Penelitian}

Pengaruh Digital Marketing (X) Terhadap Kualitas Layanan $(Y)$ melalui Media Iklan Digital di Aceh: Hasil uji validitas dari variabel Digital Marketing dan Kepuasan Layanan menggunakan perhitungan tingkat signifikansi uji dua arah 0,05 atau $5 \%$ dengan kriteria valid sebesar 0,159 . Dari hasil pengujian validitas masing-masing pernyataan dari setiap variabel nilai Item Correlations > Kriteria Valid sehingga, dapat di simpulkan bahwa seluruh instrument yang terdapat pada kuisioner dapat dinyatakan valid. Hasil Uji Reliabilitas menunjukkan bahwa nilai cronbach's alpha Based Standardized item > Kriteria Valid sebesar 0,60 sehingga, di dapat di simpulkan bahwa seluruh instrument pernyataan dari variabel Digital Marketing dan Kepuasan Layanan dapat dinyatakan reliabel. Dari hasil analisis koefisien regresi Digital Marketing sebesar 0,216 artinya setiap peningkatan Digital Marketing sebesar $1 \%$ akan meningkatkan tingkat Kualitas Layanan sebesar 21,6\%. Tanda positif menunjukkan adanya hubungan yang searah antara Digital Marketing dengan Kualitas Layanan yang berarti dalam rangka meningkatkan Tingkat Kualitas Layanan ditentukan oleh peran Digital Marketing. Hasil pengujian signifikansi menunjukkan bahwa terdapat nilai probabilitas sebesar 0,020 nilai ini berada dibawah taraf signifikansi $0,05(0,020<0,05)$, yang berarti bahwa Digital Marketing berpengaruh signifikan terhadap Kualitas Layanan melalui Aplikasi Digital di Aceh.

\section{KESIMPULAN DAN SARAN}

Seluruh pelaku Usaha menyatakan bahwa penggunaan digital marketing membantu mereka dalam meningkatkan akses terhadap konsumen (aksesibilitas) dan dengan mudah memperoleh masukan terhadap nilai produk (Interaktivitas) dalam meningkatkan kualitas layanan. Penggunaan digital marketing juga meningkatkan pemahaman konsumen terhadap produk. (kredibilitas) karena pengusaha memperbarui informasi mengenai produk. (Informatif) Selain itu dengan digital marketing, profitabilitas usaha juga meningkat.dengan adanya fitur diskon dan promo menarik yang diberikan oleh marketplace seperti Shopee, Tokopedia atau aplikasi GoFood, GrabFood bagi pelaku usaha untuk membeli produk mereka. (Hiburan) disamping itu, ada juga beberapa 
konsumen kadang merasa terganggu dengan banyaknya iklan digital atau adsense. (Gangguan) yang terkadang mengarah pada pernipuan. Kesimpulannya adalah digital marketing Digital Marketing berpengaruh signifikan terhadap tingkat Kualitas Layanan melalui Aplikasi Digital di wilayah Aceh.

\section{REFERENSI}

Badan Pusat Statistik. (2021) Jumlah Penduduk Hasil Proyeksi Menurut Provinsi dan Jenis Kelamin (Ribu Jiwa), 2018-2020, BPS, https://www.bps.go.id/indicator/12/1886/1/jumlah-penduduk-hasil-proyeksi-menurutprovinsi-dan-jenis-kelamin.html

Badan Pusat Statistik. (2021) Jumlah Total Koperasi Seluruh Aceh, Data UMKM Prov Aceh, https://datakumkm.acehprov.go.id/index.php/koperasi.

Agus S, Candra (2021) Peran Strategi Digital Marketing dan Sosial Media Dalam Bisnis Usaha Tahu Bulat De Bulat, Univ.17 Agustus 45 Surabaya.

Aileen Lee (2013) Welcome To The Unicorn Club: Learning From Billion-Dollar Startups, TechCrunch https://social.techcrunch.com/2013/11/02/welcome-to-the-unicorn-club/

Ali, H. (2013). Marketing dan Kasus-Kasus Pilihan. Yogyakarta: CAPS.

Andrew, (2021) Pengertian Revolusi Industri 4.0: Jenis, Dampak dan Contoh Penerapannya, Gramedia.com https://www.gramedia.com/best-seller/revolusi-industri-4-0/

Arifin,B, (2021) 6 Peran Penting Teknologi Informasi Dalam Bisnis, Kominfo, https://kominfo.bengkulukota.go.id/6peran-penting-teknologi-informasi-dalam-bisnis/

Arikunto, S. (2010). Metode peneltian. Jakarta: Rineka Cipta.

Chaffey, D., Chadwick, F. E., Mayer, R., \& Johnston, K. (2009). Internet Marketing: Strategy, Implementation, and Practice. United States: Prentice Hall.

Dimas (2020) Jumlah Pengguna Internet di Indonesia Capai 196,7 Juta, Databoxs, https://databoks.katadata.co.id/datapublish/2020/11/11/jumlah-pengguna-internet-di-indonesia-capai1967-juta

Elsa Catriana (2021) Kaleidoskop 2021: Tahun Penuh Harapan bagi Pelaku UMKM, Kompas.com https://money.kompas.com/read/2021/12/29/114430626/kaleidoskop-2021-tahun-penuh-harapan-bagipelaku-umkm?page=all.

Febriyantoro, M. T., \& Arisandi, D. (2018). Pemanfaatan digital marketing bagi usaha mikro, kecil dan menengah pada era masyarakat ekonomi ASEAN. Jurnal Riset Manajemen dan Bisnis Dewantara (JMD), 1(2), 61-76.

Kannan, P. K., \& Hongshuang, L. (2016). Digital Marketing: A Framework. Review and Research Agenda.

Kasali, R. (2011). Cracking Zone. Jakarta: Gramedia Pustaka Utama.

Kerlinger, F. N., Lee, H. B., \& Bhanthumnavin, D. (2000). Foundations of behavioral research: The most sustainable popular textbook by Kerlinger \& Lee (2000). Journal of Social Development, 13, 131-144.

Kumar, K., Subramanian, R., \& Strandholm, K. (2002). Market orientation and performance: Does organizational strategy matter?. Journal of Applied Business Research (JABR), 18(1). 
Kuncoro, M. (2009). Mahir Menulis: Kiat jitu menulis artikel, kolom \& resensi buku.

Mekari, (2021) Pengertian, Kelebihan, Jenis dan Strategi Digital Marketing, Jurnal Enterpreneur, https://www.jurnal.id/id/blog/mengenal-digital-marketing-konsep-danpenerapannya/\#Kelebihan_Digital_Marketing

Neter, L., Wasserman, W., \& Kutner, M. H. (1997). A Linear Model.

Sanjaya, R. (2009). Josua Tarigan. Creative Digital Marketing Teknologi berbiaya Murah, Inovatif dan Berdaya hasil gemilang. Jakarta: PT Alex Media Komputindo.

Silviana, M. (2020). Pengaruh Digital Marketing Terhadap Tingkat Penjualan Melalui Sosial Media (Studi Kasus Di Kecamatan Bone-Bone) (Doctoral dissertation, Universitas Muhammadiyah Palopo).

Simon, K, (2021) Digital 2021: Indonesia, Data Reportal, https://datareportal.com/reports/digital-2021-indonesia

Stockdale, R., Ahmed, A., \& Scheepers, H. (2012). Identifying business value from the use of social media: an SME perspective.

Sugiyono. 2009. Metode Penelitian Pendidikan Pendekatan Kuantitatif, Kualitatif, dan R \& D. Bandung : Alfabeta

Sugiyono. 2018. Metode Penelitian Kuantitatif. Bandung: Alfabeta.

Tjiptono, F., \& Arief, M. (2021). PENGARUH KUALITAS PELAYANAN TERHADAPKEPUASAN PELANGGAN KARTU PERDANA XL PADA PT. XL AXIATA Tbk CABANG MUARO BUNGO (Doctoral dissertation, Manajemen).

Wardhana, A. (2015). Determinan Kualitas Layanan Internet Banking dengan Menggunakan Metode Webqual Versi 4.0 dan Pengaruhnya Terhadap Kepuasan Nasabah Top Brand E-Channel Bank di Indonesia. IMAGE: Jurnal Riset Manajemen, 4(1).

Wardhana, A. (2015, April). Strategi digital marketing dan Implikasinya pada Keunggulan Bersaing UKM di Indonesia. In Seminar Nasional Keuangan Dan Bisnis IV (pp. 327-337).

We Are Social. (2017). Digital in 2017: Global Overview. Retrieved from https://wearesocial.com/specialreports/digital-in-2017-global-overview

Widarjono, A. (2010). Analisis statistika multivariat terapan. Yogyakarta: UPP STIM YKPN.

Yuliastini, N. K. S., Dewi, M. K. P., Wisarti, K. H., kadek Widyastuti, N., \& Winata, I. G. K. A. (2022). Pengembangan Sumber Daya Manusia Dan Manajemen Persediaan Di UD Eka Karya. ARSY: Jurnal Aplikasi Riset kepada Masyarakat, 2(2), 171-176.

Zhu, Y. Q., \& Chen, H. G. (2015). Social media and human need satisfaction: Implications for social media marketing. Business horizons, 58(3), 335-345. 